\title{
Crop yields and supply of nitrogen compared in conventional and organic farming systems
}

\author{
Maarika Alaru, Liina Talgre, Viacheslav Eremeev, Berit Tein, Anne Luik, Anu Nemvalts and Evelin Loit \\ Department of Field Crop and Grassland Husbandry, Institute of Agricultural and Environmental Sciences, Estonian University \\ of Life Sciences, Fr. R. Kreutzwaldi 1, EE51014 Tartu, Estonia \\ e-mail: maarika.alaru@emu.ee
}

\begin{abstract}
The aim of organic agriculture is to produce food of high nutritional quality in sufficient quantity. Field experiments were conducted to evaluate the effect of organic and conventional growing systems on (i) total amounts and supply of $\mathrm{N}$ taken up or applied to plants during a five year crop cycle period and (ii) crops total dry matter (DM) yield obtained during same period. The total DM yields from the organic treatments were $25-33 \%$ smaller than from the conventional treatments. The ratio of $\mathrm{N}$ output/ $\mathrm{N}$ input was significantly the smallest in the organic treatment with cattle manure, where only $37 \%$ of all supplied $N$ was used by plants during the crop cycle period. The organic fertiliser with faster mineralisation rate and splitting the application of organic $\mathrm{N}$ during crop cycle period would be more appropriate to supply sufficient quantities of $\mathrm{N}$ during rapid plant growth and to obtain higher crop yields in organic farming systems.
\end{abstract}

Key words: organic, conventional, total dry matter yield, nitrogen availability.

\section{Introduction}

In past decades, organic farming has increased rapidly in Europe (European Commission 2014). The aim of organic agriculture is to produce food in sufficient quantity while being environmentally friendly. Major challenges for organic farming are optimisation of the nutrient cycling of the agro-ecosystem and development of a more suitable alternative soil fertility strategy. Organic systems appear to be nitrogen (N) limited, whereas conventional systems are not (Berry et al. 2002, Müller et al. 2006). Crop yields of both, i.e. organic and conventional systems should be high enough for profitable production (Järvan et al. 2013). Cereal crop yields under organic management in Europe are typically $60-70 \%$ of those under conventional management (Mäder et al. 2007).

However, Pimental et al. (2005) found that depending on crop, soil, and weather conditions, organically managed crop yields on a per ha basis can equal those from conventional agriculture. Catch crops as green manure (atmospheric $\mathrm{N}$ binding legumes), cover crops in off-season period, which avoid $\mathrm{N}$ leaching in winter and composted manure as organic fertiliser are used to maintain soil organic matter and fertility (Martin 2009). Catch crops can contribute to $\mathrm{N}$ supply of following crops through uptake of excess soil mineral $\mathrm{N}$ and through biological $\mathrm{N}$ fixation (Doltra and Olesen 2013). Symbiotically fixed dinitrogen $\left(\mathrm{N}_{2}\right)$ is an important $\mathrm{N}$ source in many agricultural systems (Høgh-Jensen et al. 2004). Yet, amounts of $\mathrm{N}_{2}$ taken up by legumes and ploughed into the soil are more dependent on environmental conditions and legumes biomass. Thus the $\mathrm{N}$ is more unstable compared to the $\mathrm{N}$ amounts applied with mineral fertilisers (Russelle et al. 2013).

Winter cover crops can provide the biological $\mathrm{N}$ required by summer crops. In this field trial, winter rye (Secale cereal L.), ryegrass (Lolium multiflorum Lam.) and winter oilseed rape (Brassica napus L.) were used as cover crops in the off-season. Winter rye can provide considerable dry matter, an extensive soil-holding root system, significant reduction of $\mathrm{N}$ leaching and exceptional weed suppression. Rye is the best cool-season cereal cover for absorbing unused soil N (Müller et al. 2006). A high N user, ryegrass can capture leftover $N$ and reduce nitrate leaching over winter (Müller et al. 2006). Brassicas (canola and rapeseed, both Brassica napus L.) can provide more than $80 \%$ soil coverage when used as a winter cover crop (Haramoto and Gallandt 2004); because of their fast growth in autumn, they are well-suited to capture soil $\mathrm{N}$ remaining after crop harvest. The amount of $\mathrm{N}$ captured is mainly related to biomass accumulation and the amount of $\mathrm{N}$ available in the soil profile. Their ability to suppress soilborne disease pathogens may prove extremely beneficial (Haramoto and Gallandt 2004).

This study compared the effect of organic and conventional farming treatments on (i) total amounts and supply of $\mathrm{N}$ taken up or applied to plants during a five year crop cycle period and (ii) crops total dry matter (DM) yield obtained during same period. 


\section{Materials and methods \\ Experiment set up}

In 2008, five long-term field crop rotation experiments (CR1- CR5) of organic and conventional growing systems were established at the Estonian University of Life Sciences $\left(58^{\circ} 22^{\prime} \mathrm{N}, 26^{\circ} 40^{\prime} \mathrm{E}\right.$ ) on Stagnic Luvisol soil (sandy loam surface texture, $\mathrm{C} 1.38 \%$, and $\mathrm{N} 0.13 \%, \mathrm{pH}_{\mathrm{KCl}} 6.0$ ). The experiment was set up in a systematic block design with four replicates of each treatment and a plot size of $60 \mathrm{~m}^{2}$. These five fields or CR1-CR5 with four replications were next to each other without separation (Table 1). Organic and conventional systems were separated from each other by $18 \mathrm{~m}$ long section of mixed grasses to avoid contamination with synthetic pesticides, mineral fertilisers and cover crops. The data in the present study concerned the period 2008-2012, i.e. the first crop cycle period, during which five different crops followed each other in the order: barley (Hordeum vulgare L.) with undersown red clover, red clover (Trifolium pratense L.), winter wheat (Triticum aestivum L.), pea (Pisum sativum L.), potato (Solanum tuberosum L.). These crops are the most common in Estonian agriculture with $41 \%$ of the total cultivated area (Statistika 2014).

Table 1. Five crop rotations (CR1-CR5) on adjacent fields in 2008-2012 (one replication) and nitrogen (N) amounts applied to different organic and conventional treatments. $\mathrm{N}$ sources during crops cycle period: $\mathrm{N} 1$ and Org_1 = symbiotically fixed atmospheric $\mathrm{N}_{2} ; \mathrm{N} 2=$ $\mathrm{N}_{2}+$ mineral N 40-50 kg N ha-1; N3 = $\mathrm{N}_{2}+$ mineral N 80-100 kg N ha ${ }^{-1} ; \mathrm{N} 4=\mathrm{N}_{2}+$ mineral N 120-150 kg N ha ${ }^{-1} ;$ Org_2 $=\mathrm{N}_{2}+\mathrm{N}^{-1}$ taken up by cover crops $\mathrm{N}_{\mathrm{cC}} ;$ Org_3 $=\mathrm{N}_{2}+\mathrm{N}_{\mathrm{cC}}+\mathrm{N}$ applied with manure $\mathrm{N}_{\mathrm{m}}$

\begin{tabular}{|c|c|c|c|c|c|c|c|c|c|c|}
\hline \multirow[t]{2}{*}{ Year } & \multirow[t]{2}{*}{$\begin{array}{l}\text { Field / } \\
\text { CR* }\end{array}$} & \multirow[t]{2}{*}{ Crop } & \multicolumn{4}{|c|}{$\begin{array}{l}\text { Mineral } \mathrm{N} \text { applied }\left(\mathrm{kg} \mathrm{ha}^{-1}\right) \text { to } \\
\text { conventional treatments }\end{array}$} & & \multicolumn{3}{|c|}{$\begin{array}{l}\text { Organic } \mathrm{N} \text { applied with } \\
\text { manure }\left(\mathrm{kg} \mathrm{ha}^{-1}\right)\end{array}$} \\
\hline & & & N1 & N2 & N3 & $\mathrm{N} 4 * *$ & & Org_1 & Org_2 & Org_3 \\
\hline \multirow[t]{5}{*}{2008} & 1/CR1 & Barley + red clover & 0 & 40 & 80 & 120 & & 0 & 0 & 0 \\
\hline & $\begin{array}{l}2 / \mathrm{CR} 2 \\
3 / \mathrm{CR} 3\end{array}$ & Potato & 0 & 50 & 100 & 150 & Protective & 0 & 0 & 174 \\
\hline & 4/CR4 & Pea & 0 & 20 & 20 & 20 & area & 0 & 0 & 0 \\
\hline & 5/CR5 & Winter wheat & 0 & 50 & 100 & 150 & & 0 & 0 & 0 \\
\hline & & Red clover & 0 & 0 & 0 & 0 & & 0 & 0 & 0 \\
\hline \multirow[t]{5}{*}{2009} & 1/CR1 & Red clover & 0 & 0 & 0 & 0 & & 0 & 0 & 0 \\
\hline & 2/CR2 & Barley + red clover & 0 & 40 & 80 & 120 & Protective & 0 & 0 & 0 \\
\hline & 3/CR3 & Potato & 0 & 50 & 100 & 150 & area & 0 & 0 & 165 \\
\hline & 4/CR4 & Pea & 0 & 20 & 20 & 20 & & 0 & 0 & 0 \\
\hline & 5/CR5 & Winter wheat & 0 & 50 & 100 & 150 & & 0 & 0 & 0 \\
\hline \multirow[t]{5}{*}{2010} & 1/CR1 & Winter wheat & 0 & 50 & 100 & 150 & & 0 & 0 & 0 \\
\hline & 2/CR2 & Red clover & 0 & 0 & 0 & 0 & Protective & 0 & 0 & 0 \\
\hline & 3/CR3 & Barley + red clover & 0 & 40 & 80 & 120 & area & 0 & 0 & 0 \\
\hline & 4/CR4 & Potato & 0 & 50 & 100 & 150 & & 0 & 0 & 183 \\
\hline & 5/CR5 & Pea & 0 & 20 & 20 & 20 & & 0 & 0 & 0 \\
\hline \multirow[t]{5}{*}{2011} & 1/CR1 & Pea & 0 & 20 & 20 & 20 & & 0 & 0 & 0 \\
\hline & 2/CR2 & Winter wheat & 0 & 50 & 100 & 150 & Protective & 0 & 0 & 0 \\
\hline & 3/CR3 & Red clover & 0 & 0 & 0 & 0 & area & 0 & 0 & 0 \\
\hline & 4/CR4 & Barley + red clover & 0 & 40 & 80 & 120 & & 0 & 0 & 0 \\
\hline & 5/CR5 & Potato & 0 & 50 & 100 & 150 & & 0 & 0 & 169 \\
\hline \multirow[t]{5}{*}{2012} & 1/CR1 & Potato & 0 & 50 & 100 & 150 & & 0 & 0 & 179 \\
\hline & 2/CR2 & Pea & 0 & 20 & 20 & 20 & Protective & 0 & 0 & 0 \\
\hline & 3/CR3 & Winter wheat & 0 & 50 & 100 & 150 & area & 0 & 0 & 0 \\
\hline & 4/CR4 & Red clover & 0 & 0 & 0 & 0 & & 0 & 0 & 0 \\
\hline & 5/CR5 & Barley + red clover & 0 & 40 & 80 & 120 & & 0 & 0 & 0 \\
\hline
\end{tabular}

*1/CR1-5/CR5 - five fields with their crop rotation 
The five field crop rotation experiments were treated using different farming systems: three organic (Org_1, Org_2 and Org_3) and four conventional (N1, N2, N3, N4) (Table 1). The influence of organic and mineral nitrogen $(\mathrm{N})$ on crops total DM yield and winter wheat yield quality in the first crop cycle period were studied. The first organic treatment Org_1 was a control, with symbiotically fixed atmospheric $\mathrm{N}_{2}$ the only source of $\mathrm{N}$, ploughed into the soil with legume above-ground biomass (red clover and pea, i.e. twice during the crop cycle period). In the second organic treatment Org_2, in addition to legumes, cover crops were used as green manure in winter: after crops of winter wheat, potato and pea, the cover crops ryegrass (Lolium perenne L.), winter rye (Secale cereale L.) and winter oilseed rape (Brassica napus ssp. oleifera var. biennis), respectively, were sown. Rye fibrous root system can take up and hold as much as $90 \mathrm{~kg} \mathrm{ha}^{-1}$ until spring, with 30 to $60 \mathrm{~kg} \mathrm{~N} \mathrm{ha}^{-1}$ more typical (Müller et al. 2006). Winter oilseed rape's extensive, fibrous root system can take up as much as 50-80 kg N ha-1 (Müller et al. 2006). Cover crops were ploughed into the soil as soon as possible after the snow melted in April. The $\mathrm{N}$ amounts taken up by legumes and cover crops were calculated (see the Calculation of $\mathrm{N}_{2}$ fixation chapter). In the third organic treatment Org_3, fully composted cattle manure was added once during the crop cycle, before potato. It was ploughed into the soil in the autumn at the end of September or beginning of October before sowing of winter oilseed rape as the cover crop at a rate of $40 \mathrm{t} \mathrm{ha}^{-1}$. The chemical properties of the composted cattle manure and N, P, K amounts applied with manure are shown in Table 2.

\begin{tabular}{lllllll}
\hline \multicolumn{6}{l}{ Table 2. The chemical properties of manure and $\mathrm{N}, \mathrm{P}, \mathrm{K}$ amounts applied with manure in 2008-2012 } \\
\hline Year & $\mathrm{pH}_{\mathrm{KCl}}$ & $\mathrm{DM}(\%)^{*}$ & $\mathrm{C}_{\mathrm{tot}}(\%)$ & $\mathrm{N}\left(\mathrm{kg} \mathrm{ha}^{-1}\right)$ & $\mathrm{P}\left(\mathrm{kg} \mathrm{ha}^{-1}\right)$ & $\mathrm{K}\left(\mathrm{kg} \mathrm{ha}^{-1}\right)$ \\
\hline 2008 & 7.0 & 42.4 & 139 & 174 & 82 & 154 \\
2009 & 7.0 & 41.7 & 126 & 165 & 75 & 175 \\
2010 & 6.8 & 48.2 & 150 & 183 & 90 & 166 \\
2011 & 5.7 & 43.9 & 133 & 169 & 87 & 130 \\
2012 & 7.0 & 48.0 & 141 & 179 & 78 & 145 \\
\hline
\end{tabular}

*DM - dry matter

$\mathrm{N}$ source of the first conventional treatment N1 was the same as for the Org_1 treatment, i.e. atmospheric $\mathrm{N}_{2}$ fixed by legumes in crop rotations; mineral $\mathrm{N}$ fertilisers were not added. The other three conventional treatments $\mathrm{N} 2$, N3 and N4, had additional N-P-K fertilisers applied at planting at the rate of 20-25-95 kg ha-1, whereas amounts of $\mathrm{P}$ and $\mathrm{K}$ were similar in all treatments. One and/or two subsequent $\mathrm{N}$ supplements were added during growth (N2 = 20-30 kg N ha ${ }^{-1}$; N3 = 60-80 kg N ha ${ }^{-1}$; and N4 = 100-130 kg N ha-1). Lower amounts of $\mathrm{N}$ were used for the barley crop with undersown red clover; red clover alone did not receive any mineral fertilisers. Pea as a leguminous crop received mineral $\mathrm{N}$ in amount of $20 \mathrm{~kg} \mathrm{~N} \mathrm{ha}^{-1}$ in N2, N3 and N4 treatments.

The tillage method in all treatments was mouldboard ploughing to a depth of $20 \mathrm{~cm}$. The conventional systems were treated with several synthetic pesticides one to four times during crop growth as required. In the organic systems, weed control after sowing and in the winter wheat field at the end of April was carried out by spring-tine harrowing. In the potato field, winter-row cultivation was used three times. The cultivars used in this trial were mostly local cultivars bred at the Estonian Plant Breading Institute: the domestic early to medium potato cultivar 'Reet', the local barley cultivar 'Leeni', the winter wheat cultivar 'Portal', the pea cultivar 'Madonna' and the red clover cultivar 'Jõgeva 205'. These cultivars are recommended for organic farming (Tsahkna and Tähtjärv 2008). In all treatments the red clover was cut and ploughed into the soil in the last two weeks of August.

The above ground biomass samples (with roots) of winter wheat, barley + red clover and pea crop were taken from the test plot size of $0.3 \mathrm{~m}^{2}$ and red clover crop samples from the test plot size of $1 \mathrm{~m}^{2}$. Samples were taken before harvest every year. Winter wheat, barley and pea were harvested with Sampo combine harvester with header width of $3 \mathrm{~m}$, i.e. the test area for grain yield calculation was $30 \mathrm{~m}^{2}$. The number of indicators used in statistical analysis was 140 for each crop ( 7 treatments $\times 4$ replication $x 5$ years). The samples were dried $48 \mathrm{~h}$ at the temperature $105{ }^{\circ} \mathrm{C}$ for biomass dry matter (DM) measurement. Potato DM measurements are previously described (Tein et al. 2014). 


\section{Chemical analysis}

Total nitrogen $\left(\mathrm{N}_{\text {tot }}\right)$, carbon $\left(\mathrm{C}_{\text {tot }}\right)$ content of oven-dried manure and plant samples were determined by dry combustion method on a varioMAX CNS elemental analyzer (ELEMENTAR, Germany) (Methods of Soil and Plant Analysis 1986). Acid digestion by sulphuric acid solution was used to determine cattle manure $P_{\text {tot }}$ and $K_{\text {tot }}$ concentrations. Once a year in mid-April before the start of field operations, soil samples were taken from a depth of 0-25 $\mathrm{cm}$. Air-dried soil samples were sieved through a 2-mm sieve and used to determine soil reaction $(\mathrm{pH})$ in $1 \mathrm{M} \mathrm{KCl}$ $1: 2.5$, organic carbon $\left(\mathrm{C}_{\text {org }}\right.$ ) after Tjurin (Soil Survey Laboratory Staff 1996), the content of total $N\left(N_{\text {tot }}\right)$ after Kjeldahl was measured (van Reeuwijk 1995).

\section{Calculation of $\mathrm{N}_{2}$ fixation}

A simple empirical model was used to quantify symbiotic $N_{2}$ fixation by legumes (SNF) (Høgh-Jensen et al. 2004). The model was modified for this study and estimated SNF using DM yield as input and parameters for (i) $\mathrm{N}$ concentration in DM and (ii) the proportion of $\mathrm{N}$ in the legume derived from the atmosphere:

$S N F=M_{\text {legume }} \times N \% \times P_{\text {fix }} \times 1.55$

where $\mathrm{DM}_{\text {legume }}=$ accumulated amount of legume shoot $\mathrm{DM}$ above normal defoliation height; $\mathrm{N} \%$ = concentration of $\mathrm{N}$ in the DM of legume $\left(\mathrm{kg} \mathrm{kg}^{-1}\right) ; \mathrm{P}_{\text {fix }}=$ fixed $\mathrm{N}_{2}$ in the root and stubble as a proportion of totally fixed shoot $\mathrm{N}$ at the end of the growing period; $P_{\text {fix }}$ for red clover and pea crop used in this study was 0.84 and 0.71 , respectively (Amossé 2013); 1.55 = the coefficient for calculation of $\mathrm{N}$ content in below ground plant parts (Rietberg et al. 2014). Using total $\mathrm{N}$ uptake by cover crops ( $\mathrm{N}$ concentration multiplied by above-ground biomass yield), we calculated the $\mathrm{N}$ amount ploughed into the soil with cover crop biomass ( $\mathrm{N}$ input into the soil).

\section{$\mathrm{N}$ efficiency analysis}

Definition of nutrient use efficiency included harvestable product per unit of nutrient applied (Caradus 1990). Nitrogen use efficiency (NUE, $\mathrm{kg} \mathrm{DM} \mathrm{kg}^{-1} \mathrm{~N}^{-1}$ ), in our trial, was calculated as follows (Pandey et al. 2001):

$$
\text { NUE }=\frac{\text { Treatment harvestable product }}{\text { Total amount of } \mathrm{N} \text { applied and taken up by legumes and cover crops }}
$$

The efficiency of apparent $\mathrm{N}$ recovery of the supplied amendments, i.e. percent recovery of $\mathrm{N}$ was determined as follows (Pandey et al. 2001, Cassmann 2002):

$$
\% \text { Recovery }=\frac{\text { Treatment uptake (output) }}{\text { Total amount of } \mathrm{N} \text { applied and taken up legumes and cover crops! }} \times 100
$$

\section{Weather conditions}

Meteorological data were collected from a meteorological station approximately $2 \mathrm{~km}$ from the trial site. Temperatures in 2008-2012 were similar to the long-term average, only in 2010 were higher than usual (in July the temperature was $4.7^{\circ} \mathrm{C}$ higher than the long-term average). Total precipitation during the growth period of 20082010 (May-September) was similar to the long-term average of $351 \mathrm{~mm}$. In 2011, precipitation in June-August was considerably lower than the long-term average, only $138 \mathrm{~mm}$, i.e. $98 \mathrm{~mm}$ lower. 2012 was the most favourable for plant growth, with temperature similar to the long-term average, but total precipitation during the growth period of 2012 was $102 \mathrm{~mm}$ higher than usual. 


\section{Statistical analyses}

Correlation, factorial analyses of variance (ANOVA) and two-factor ANOVA were used to test the effect of farming systems and experimental year on different crops DM yield and winter wheat quality. Descriptive analysis and Fisher's least significant difference test for homogenous groups were used for testing significance differences between farming systems, experimental year and crops mean DM yields. The means are presented with/or without their standard errors ( \pm SE) (bars in the figures). The level of statistical significance was set at $p<0.05$ if not indicated otherwise.

\section{Results and discussion}

\section{$\mathrm{N}$ input in different farming treatments during the first crop cycle period 2008-2012}

This study focused on the $\mathrm{N}$ supply as the most important nutrient in terms of high crop yield formation. Pang and Letey (2000) reported that $\mathrm{N}_{2}$-fixing crops are a very important source of $\mathrm{N}$ in organic farming systems and therefore legumes often are included in crop rotations. Pea and red clover as commonly used legumes in Estonian agriculture were incorporated to this five field crop rotation experiment; in organic farming systems additionally to $\mathrm{N}_{2}$ the well composted manure and cover crops were used to supply plants with sufficient amounts of N. However, the agronomic techniques or measures used in organic farming may not always lead to the desired result, i.e. to a higher crop yield, because the amounts and mineralisation of plant-available organic $\mathrm{N}$ are very environmentdependent, which may lead to $\mathrm{N}$ limitation due to approximate calculation (Russelle et al. 2013).

The total $\mathrm{N}$ amounts applied with fertilisers and taken up by legumes and cover crops during the first crop cycle period 2008-2012 for different organic and conventional treatments was the greatest in conventional treatment N4 and the least in organic and conventional control treatments (Org_1 and N1) (Fig. 1).

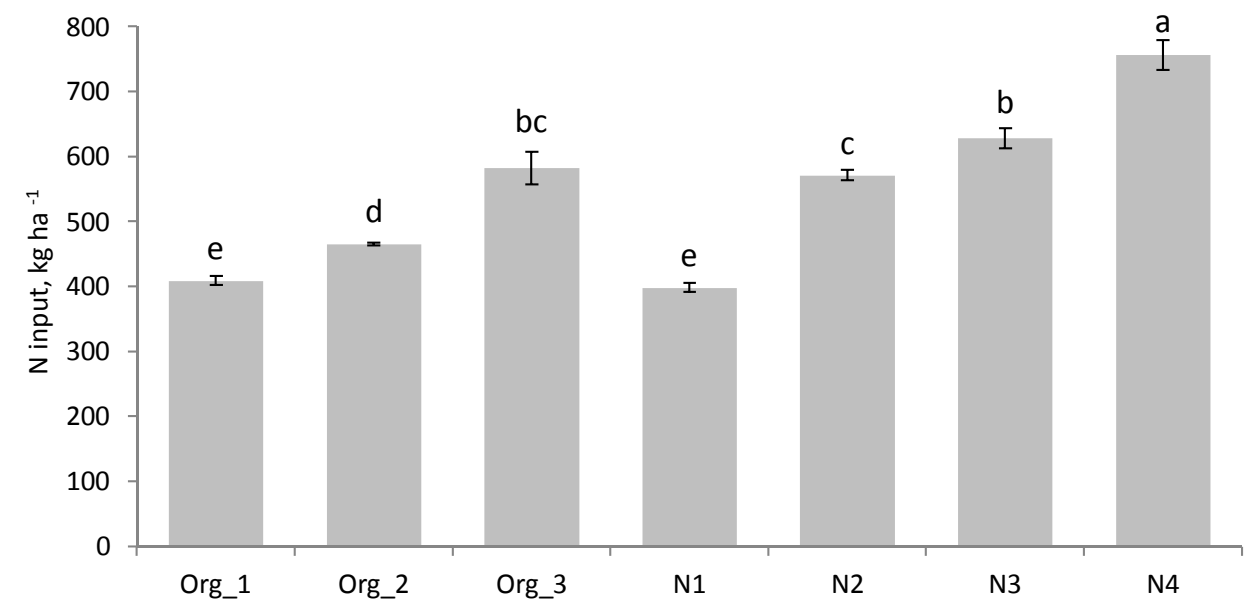

Fig. 1. The sum of $\mathrm{N}$ amounts taken up or applied during the first crop cycle period 2008-2012 for different organic and conventional treatments as an average of CR1-CR5. N sources during crops cycle period: N1 and Org_1 = symbiotically fixed atmospheric $\mathrm{N}_{2} ; \mathrm{N} 2=\mathrm{N}_{2}+$ mineral $\mathrm{N} \mathrm{40-50} \mathrm{kg} \mathrm{N} \mathrm{ha-1;} \mathrm{N} 3=\mathrm{N}_{2}+$ mineral N 80-100 kg N ha ${ }^{-1} ; \mathrm{N} 4=\mathrm{N}_{2}+$ mineral N 120-150 kg N ha- ${ }^{-1} ;$ Org_2 $=\mathrm{N}_{2}+\mathrm{N}$ taken up by cover crops $\mathrm{N}_{\mathrm{cc}} ;$ Org_3 $=\mathrm{N}_{2}+\mathrm{N}_{\mathrm{cC}}+\mathrm{N}$ applied with manure $\mathrm{N}_{\mathrm{m}}$ Different letters denote significant differences between treatments and bars denote $\pm \mathrm{SE}$.

For example, the total amount of $\mathrm{N}$ calculated for the $\mathrm{N} 4$ treatment was $756 \pm 23 \mathrm{~kg} \mathrm{~N} \mathrm{ha}^{-1}$, but the same data for Org_1 and N1 were $409 \pm 7$ and $397 \pm 3 \mathrm{~kg} \mathrm{~N} \mathrm{ha}^{-1}$, respectively. $\mathrm{N}$ source of treatments Org_1 and N1 (as controls for organic and conventional systems, respectively) was the same, i.e. atmospheric $\mathrm{N}_{2}$ fixed by legumes pea and red clover crops during the crop cycle period. These treatments differed from one another in terms of chemical pesticide use. The $\mathrm{N}$ amounts taken up by the pea and red clover crops ranged over years and crop rotations between 64.5-92.7 and 195.2-293.6 $\mathrm{kg} \mathrm{N} \mathrm{ha}^{-1}$, respectively. The smallest amount of $\mathrm{N}$ taken up by the pea crop was in the Org_1 treatment, followed by Org_3 treatment; and the highest amount of $\mathrm{N}$ taken up by the pea crop was in N2, followed by N3 treatment. The smallest amount of $\mathrm{N}$ taken up by red clover crop was in the N4 treatment, followed by N3 and the highest amount was in Org_2, followed by N1 treatment. 
$\mathrm{N}$ uptake by off-season cover crops was quite small because of small above ground biomasses. $\mathrm{N}$ amounts ploughed into the soil with winter cover crops varied with year and crop rotations between 7.81-16.0 $\mathrm{kg} \mathrm{N} \mathrm{ha}^{-1}$, with the smallest amount of $\mathrm{N}$ obtained from winter oil seed rape and the highest from winter rye biomasses. The $\mathrm{N}$ amounts obtained by winter cover crops were, in this trial, much lower than reported in the literature (Müller et al. 2006). Probably, this was caused by the smaller above ground biomasses obtained due to longer winter and shorter growth period; the growth period of winter cover crops in Estonian climatic conditions usually lasts until freezing of ground, i.e. only 30-40 days for rye, up to 70 days for ryegrass and winter oil seed rape with 50-55 days more typical. The total $\mathrm{N}$ amount of the first crop cycle period in the organic treatment Org_2 was 95-139 kg N ha-1 lower than of the third organic treatment Org_3.

The $\mathrm{N}$ amounts applied with well composted cattle manure ranged over years and crop rotations between 169$180 \mathrm{~kg} \mathrm{~N} \mathrm{ha}{ }^{-1}$. The $\mathrm{N}$ content of the well-composted manure used in this study was much lower than reported in the literature (Vettik and Tamm 2013); usually the N content of manure in DM is $1.5-2.0 \%$ whereas in this study it was below $1 \%$. The same amounts of $\mathrm{N}$ were provided for the organic treatment with manure Org_3 and for the conventional treatment N2 (Fig. 1): $582 \pm 25$ and $571 \pm 7 \mathrm{~kg} \mathrm{~N} \mathrm{ha}^{-1}$, respectively.

\section{The total DM yields of crops in the first crop cycle period 2008-2012}

The $\mathrm{N}$ treatment and weather conditions affected the total harvestable yield of crops in DM significantly; the proportion of variation for organic treatments was $10 \%$ and $86 \%$, respectively and for conventional treatments $30 \%$ and $65 \%$, respectively. The proportion of variation confirmed that crops yields in organic systems were sensitive to weather conditions. The higher total DM yields of different crop rotations were mostly obtained from treatments fertilised with mineral $\mathrm{N}$. In all conventional treatments fertilised with mineral $\mathrm{N}$ the total harvestable yield in DM was the same (Fig.2).

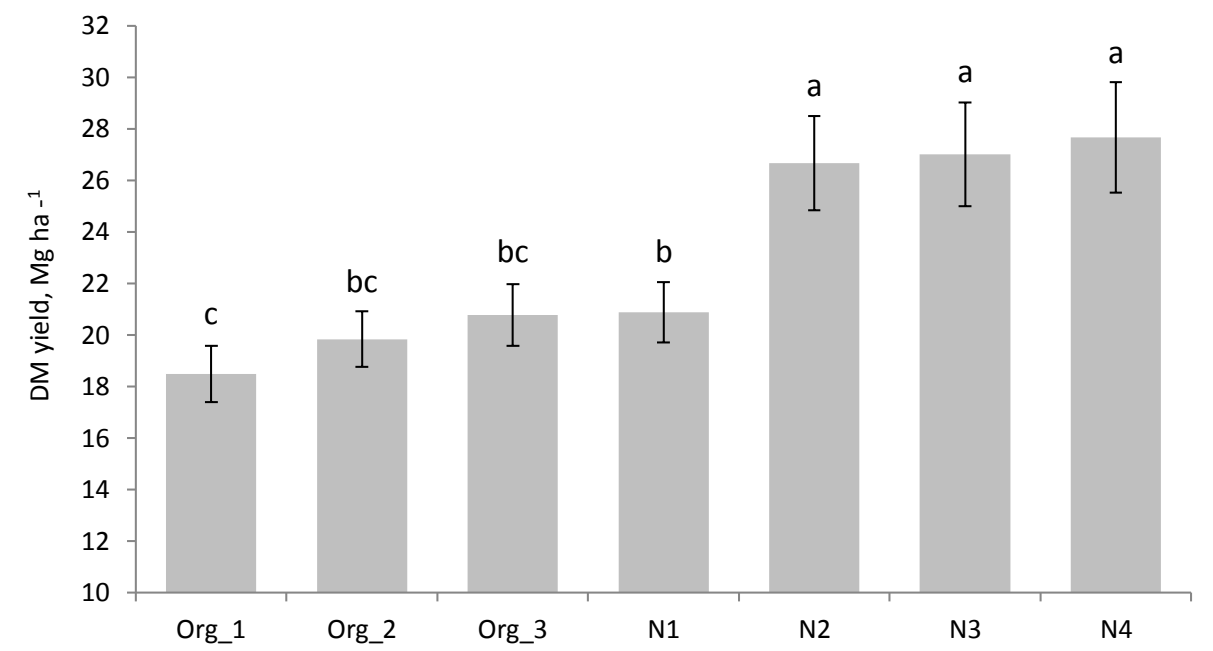

Fig. 2. The influence of organic and conventional $\mathrm{N}$ treatments on the crops total DM yields obtained in 2008-2012 as an average of CR1-CR5. N sources during crops cycle period: N1 and Org_1 = symbiotically fixed atmospheric $\mathrm{N}_{2} ; \mathrm{N} 2=\mathrm{N}_{2}+$ mineral $\mathrm{N} 40-50 \mathrm{~kg} \mathrm{~N}$ ha-1 $; \mathrm{N} 3=\mathrm{N}_{2}+$ mineral N 80$100 \mathrm{~kg} \mathrm{~N} \mathrm{ha}^{-1} ; \mathrm{N} 4=\mathrm{N}_{2}+$ mineral N 120-150 kg N ha ${ }^{-1} ;$ Org_2 $=\mathrm{N}_{2}+\mathrm{N}$ taken up by cover crops $\mathrm{N}_{c \mathrm{c}}$; Org_3 $=\mathrm{N}_{2}+\mathrm{N}_{\mathrm{cC}}+\mathrm{N}$ applied with manure $\mathrm{N}_{\mathrm{m}}$ Different letters denote significant differences between treatments and bars denote \pm SE.

As an average of five crop rotations CR1-CR5 the total harvestable yields in DM of the whole crop cycle period obtained from the organic treatments were 25-33\% smaller than those from the conventional treatments fertilised with mineral N (Fig. 2.). These results are consistent with literature data. Seufert et al. (2012) reported that organic yields are typically 5-34\% lower than conventional yields, but that, with good management practices, organic yields can nearly match conventional yields. In this study, despite the use of various technologies in the organic system, yields were still up to $30 \%$ lower than in the conventional system. Fertilisation with well-composted cattle manure or cover crops cultivation did not increase the crops DM yield in the organic treatments. Moreover, the yields did not differ from each other in organic treatments. This suggests that most of $\mathrm{N}$ applied with manure was not available to plants in their growth period, which could be caused by several factors. 
Organic $\mathrm{N}$ is converted to inorganic $\mathrm{N}$ and made available for plant growth during the manure mineralisation process. Only $20 \%$ of $\mathrm{N}$ in manure is mineralised during the first year (Kärblane 1996, Pang and Letey 2000). In our trial, the manure used had a high DM content (44\%), aerobically mineralised for long time during which the large part of $\mathrm{N}$ could be released to the atmosphere. The low efficiency of used manure was probably caused by low $\mathrm{N}$ content and by applying the manure only once during crop cycle period. It would be worth to determine the most appropriate number of manure applications in the future.

The $\mathrm{N}$ availability during the early growth period of cereal crops is an essential factor in terms of their above ground biomass formation; grain yield and the above ground biomass yield in this trial correlated significantly with crop yield $(p<0.001)$. For example, above ground biomass yields of barley in all organic treatments were the same varying between 3.69 and $4.40 \mathrm{Mg} \mathrm{ha}^{-1}$, barley grain yield varied between $1.76-2.17 \mathrm{Mg} \mathrm{ha}^{-1}$; by contrast in all conventional treatments, the above ground biomass varied between $7.73-7.99 \mathrm{Mg} \mathrm{ha}^{-1}$ (also the same) and grain yield varied between 3.79-4.31 $\mathrm{Mg} \mathrm{ha}^{-1}$. The same data for winter wheat were 9.70-11.53 and 3.81-3.83 $\mathrm{Mg} \mathrm{ha}^{-}$ ${ }^{1}$, respectively; $12.36-15.08$ and $5.16-5.58 \mathrm{Mg} \mathrm{ha}^{-1}$, respectively. These results are consistent with literature data (Donmez et al. 2001, White and Wilson 2006). Mostly the yield level of cereals depends on N availability during tillering and stem elongation stages and $\mathrm{N}$ deficit at this time results in much lower grain yield (Alaru et al. 2009).

In the table 3 the mean DM yield of different crops grown in all organic and conventional treatment $\mathrm{N} 2$ has been compared. Despite the fact that N amounts of Org_3 and N2 treatments were the same, the level of harvestable yield in DM for different crops in Org_3 treatment was 16-43\% lower than that of N2. The yield of potato and barley crops decreased in organic $N$ treatments significantly, whereas mean DM yield level of legumes crops was the same in these treatments. Mean DM yield of barley decreased because of higher red clover biomass yield in organic treatments (red clover was sown with barley).

Table 3. Mean DM yield ( \pm SE) of different crops over crop rotations in comparison of all organic and $\mathrm{N} 2$ treatments. $\mathrm{N}$ sources during crops cycle period: Org_1 = symbiotically fixed atmospheric $\mathrm{N}_{2} ;$ Org_2 $=\mathrm{N}_{2}+\mathrm{N}$ taken up by cover crops $\mathrm{N}_{c c} ;$ Org_3 $=\mathrm{N}_{2}+\mathrm{N}_{c C}+\mathrm{N}$ applied with manure $\mathrm{N}_{\mathrm{m}} ; \mathrm{N} 2=\mathrm{N}_{2}+$ mineral $\mathrm{N} 40-50 \mathrm{~kg} \mathrm{~N}^{-1}$. Different letters in rows denote significant differences between treatments.

\begin{tabular}{lcccc}
\hline \multirow{2}{*}{ Crop } & \multicolumn{4}{c}{ Mean DM yield $\left(\mathrm{Mg} \mathrm{ha}^{-1}\right)$} \\
& Org_1 & Org_2 & Org_3 & N2 \\
\hline Potato & $7.7 \pm 1.04 \mathrm{~b}^{* *}$ & $7.3 \pm 0.89^{\mathrm{b}}$ & $8.8 \pm 1.09^{\mathrm{b}}$ & $11.6 \pm 1.30^{\mathrm{a}}$ \\
Barley with undersown & & & \\
red clover & $1.4 \pm 0.18^{\mathrm{c}}$ & $1.7 \pm 0.27^{\mathrm{bc}}$ & $2.0 \pm 0.32^{\mathrm{b}}$ & $3.5 \pm 0.37^{\mathrm{a}}$ \\
Red clover & $4.9 \pm 1.11^{\mathrm{a}}$ & $5.8 \pm 1.21^{\mathrm{a}}$ & $4.9 \pm 1.06^{\mathrm{a}}$ & $4.5 \pm 0.18^{\mathrm{a}}$ \\
Winter wheat & $2.3 \pm 0.59^{\mathrm{b}}$ & $2.9 \pm 0.66^{\mathrm{ab}}$ & $2.9 \pm 0.77^{\mathrm{ab}}$ & $4.3 \pm 0.85^{\mathrm{a}}$ \\
Pea & $2.1 \pm 0.23^{\mathrm{a}}$ & $2.1 \pm 0.24^{\mathrm{a}}$ & $2.1 \pm 0.23^{\mathrm{a}}$ & $2.5 \pm 0.22^{\mathrm{a}}$ \\
\hline
\end{tabular}

The coefficient of variation for all crops in organic treatments ranged between $24-59 \%$ and the same data for conventional treatment N2 was 9-37\% with the highest value of winter wheat yield in all treatments. The coefficient of variation for different crops confirmed that crops yields in organic treatments were more weather-dependent than yields of conventional treatment.

To increase the crops DM yield in organic treatments, the organic fertiliser with faster mineralisation rate and splitting the application of organic $\mathrm{N}$ in crop cycle period would be more appropriate to supply sufficient quantities of $\mathrm{N}$ during rapid plant growth. For example, part of the amount of $\mathrm{N}$ would be applied as liquid organic fertiliser like bioslurry or an anaerobically digested slurry with DM content below $18 \%$ to winter wheat in early spring during tillering, which would be increase the crop yield in organic farming systems.

\section{$\mathrm{N}$ use efficiency (NUE)}

NUE was calculated as $1 \mathrm{~kg}$ total DM yield per $1 \mathrm{~kg}$ of $\mathrm{N}$ applied or fixed symbiotically by legumes or collected by cover crops during the whole five year crop cycle period. Higher NUE revealed in treatments with lower amounts of N, i.e. Org_1, Org_2, N1, N2 (45.1, 42.7, 52.6 and 46.8 kg DM per 1 kg N, respectively). Probably DM of Org_1 and $\mathrm{N} 1$ treatments yields partially at the expense of soil N. Treatments in which the supply of N was increased (Org_3 and N4) had the same and significantly the lowest NUE - 36.0 and $36.9 \mathrm{~kg}$ DM per $1 \mathrm{~kg} \mathrm{~N}$, respectively. These re- 
sults are in agreement with previous studies. Pask et al. (2012) reported that N-utilisation efficiency and biomass production efficiency ( $\mathrm{kg} \mathrm{DM} \mathrm{kg}^{-1} \mathrm{~N}$ ) showed an inverse relationship with $\mathrm{N}$ uptake by plants; Foulkes et al. (1998) showed that biomass production efficiency decreased with increasing $\mathrm{N}$ supply. In this study, the total $\mathrm{N}$ input of organic treatment Org_1 ( $\mathrm{N}$ taken up by pea and red clover) was 12-30\% lower than of Org_2 and Org_3, respectively, but the total DM yield of Org_1 was the same as other organic treatments. These results validate that additional amounts of organic $\mathrm{N}$ from cover crops and manure were not available to plants to increase the yield. To increase the NUE of organic systems, it is important to find a fertilising system, which provides sufficient $\mathrm{N}$ in the early stages of plant development (Seufert et al. 2012).

\section{$\mathrm{N}$ recovery \%}

$\mathrm{N}$ recovery (\%) characterizes the proportion of $\mathrm{N}$ carried from the field with plant biomass ( $\mathrm{N}$ output) per all amounts of $\mathrm{N}$ applied or fixed during five year crop cycle period ( $\mathrm{N}$ input). The ratio of $\mathrm{N}$ output / $\mathrm{N}$ input was the smallest in Org_3 treatment, where only $37 \%$ of all supplied $N$ was used by plants during the five year crop cycle period. This was expected and coincides with literature data (Cusick et al. 2006). N amounts used by plants of different conventional treatments were significantly higher varying between $54-57 \%$ (Fig. 3).

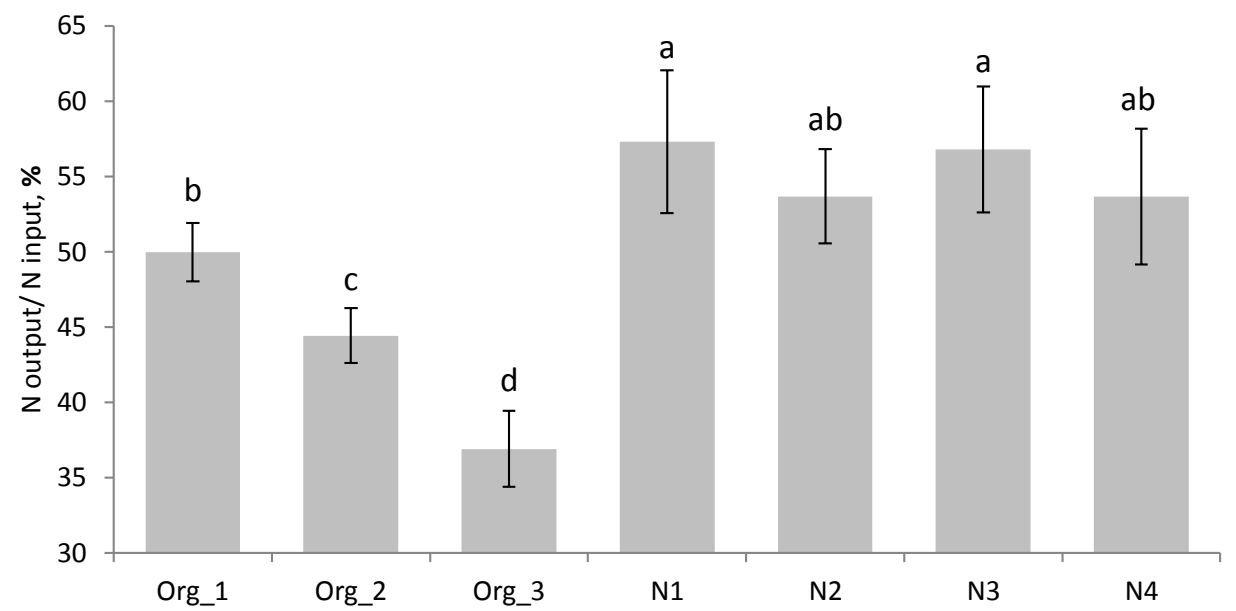

Fig. 3. $\mathrm{N}$ output and input, the ratio of the percentage; $\mathrm{N}$ recovery (\%) of different fertilizing treatments. $\mathrm{N}$ sources during crops cycle period: $\mathrm{N} 1$ and Org_1 = symbiotically fixed atmospheric $\mathrm{N}_{2} ; \mathrm{N} 2=\mathrm{N}_{2}+$ mineral N 40-50 kg N ha- ${ }^{-1}$ N3 $=\mathrm{N}_{2}+$ mineral N 80-100 kg N ha-1; $\mathrm{N}^{-1}=\mathrm{N}_{2}+$ mineral N 120-150 kg N ha${ }^{1} ;$ Org_2 $=\mathrm{N}_{2}+\mathrm{N}$ taken up by cover crops $\mathrm{N}_{\mathrm{cc}} ; \mathrm{Org} \_3=\mathrm{N}_{2}+\mathrm{N}_{\mathrm{cC}}+\mathrm{N}$ applied with manure $\mathrm{N}_{\mathrm{m}}$. Different letters denote significant differences between treatments and bars denote $\pm \mathrm{SE}$.

\section{Conclusions}

The agronomic technics used in this study (fertilisation with well-composted cattle manure or cover crops cultivation) did not increase the total DM yield in organic treatments. The total DM yields of whole crop cycle period obtained from different organic treatments were $24-33 \%$ smaller than yields from conventional treatments. The ratio of $\mathrm{N}$ output / $\mathrm{N}$ input was significantly the smallest in organic treatment with manure, where only $37 \%$ of all supplied $\mathrm{N}$ was used by plants during five year crop cycle period. $\mathrm{N}$ amounts used by plants of different conventional treatments were significantly higher varying between $54-57 \%$. This could be caused by several factors like manure application once during crop cycle period and low $\mathrm{N}$ content of used well composted manure. The organic fertiliser with faster mineralisation rate and splitting the application of organic $\mathrm{N}$ during crop cycle period would be more appropriate to supply sufficient quantities of $\mathrm{N}$ during rapid plant growth and to obtain higher crop yields in organic farming systems.

\section{Acknowledgements}

The study has been supported by Estonian University of Life Sciences project 8-2/P13001PKTM, by Estonian Government Target Financing project SF170057s09 and by ERA-NET CORE-ORGANIC II project TILMAN - ORG. We thank prof. Ingrid Williams for her linguistic help with this manuscript 


\section{References}

Alaru, M., Laur, Ü., Eremeev, V., Reintam, E., Selge, A. \& Noormets, M. 2009. Winter triticale yield formation and quality affected by $\mathrm{N}$ rate, timing and splitting. Agricultural and food science 18: 76-90.

Amossé, C., Jeuffroy, M-H., Celette, F. \& David, C. 2013. Relay-intercropped forage legumes help to control weeds in organic grain production. European Journal of Agronomy 49: 158-167.

Berry, P.M., Stockdale, E.A., Sylvester-Bradley, R., Phillipps, L., Smith, K.A., Lord, E.I., Watson, C.A. \& Fortune, S. 2002. N, P and K budgets for crop rotations on nine organic farms in the UK. Soil use and management 18: 248-255.

Caradus, J.R. 1990. Mechanisms improving nutrient use by crop and herbage legumes. In: Baligar, V.C. \& Duncan, R.R. (eds.). Crops as enhancers of nutrient use. San Diego, California: Academic Press. p. 253-311.

Cassman, K. G., Dobermann, A. \& Walters, D. T. 2002. Agroecosystems, Nitrogen-use Efficiency, and Nitrogen Management. Journal of the Human Environment 31: 132-140.

Cusick, P.R., Kelling, A.K., Powell, J.M. \& Muñoz, G.R. 2006. Estimates of Residual Dairy Manure Nitrogen Availability Using Various Techniques. Journal of Environmental Quality 35: 2170-2177.

Doltra, J. \& Olesen, E.J. 2013. The role of catch crops in the ecological intensification of spring cereals in organic farming under Nordic climate. European Journal of Agronomy 44: 98-108.

Donmez, E., Sears, R.G., Shroyer, J.P. \& Paulsen, G.M. 2001. Genetic gain in yield attributes of winter wheat in the Great Plains. Crop Science 41: 1412-1419.

Foulkes, M.J., Sylvester-Bradley, R. \& Scott, R.K. 1998. Evidence for differences between winter wheat cultivars in acquisition of soil mineral nitrogen and uptake and utilization at applied fertilizer nitrogen. Journal of Agricultural Science 130: 29-44.

European Commission 2014. Communication from the commission to the European Parliament, the Council, the European Economic and Social Committee and the Committee of the Regions. Brussels, 24.3.2014, COM (2014) 179 final. http://ec.europa.eu/ agriculture/organic/documents/eu-policy/europ. Accessed 16 June 2014.

Haramoto, E.R. \& Gallandt, E.R. 2004. Brassica cover cropping for weed management: a review. Renewable Agriculture and Food Systems 19:187-198.

Høgh-Jensen, H., Loges, R., Jørgensen, F.V., Finn P., Vinther, F.P. \& Jensen, E.S. 2004. An empirical model for quantification of symbiotic nitrogen fixation in grass-clover mixtures. Agricultural Systems 82: 181-194.

Järvan, M., Edesi, L., Paivel, M., Adamson, A., Akk, E., Kuuskla, M., Kala, R., Laitamm, H., Lukme, L., Akk, A. \& Luik, S. 2013. Impact of different cultivation practices on the crop yields, yield quality, the agrochemical and agrophysical indicators of soil, the microbial community and microbial activity of the soil, and weeds on the rotation plots. Raport for the Estonian Ministry of Agriculture. 42 p. (in Estonian).

Kärblane, H. 1996. Taimede toitumise ja väetamise käsiraamat. Tallinn: Tallinna Raamatutrükikoda. 283 p. (in Estonian).

Martin, H. 2009. Introduction to organic farming. Ministry of Agriculture, Food and Rural Affairs. OMAFRA Factsheet 06-103. ORDER NO. 09-077 AGDEX 100/10. http://www.omafra.gov.on.ca/english/crops/facts/09-077.pdf. Accessed 19 March 2014.

Methods of Soil and Plant Analysis 1986. Agricultural Research Centre, Department of Soil Science. Jokioinen, Finland. 45 p.

Mäder, P., Hahn, D., Dubois, D., Gunst, L., Alföldi, T., Bergmann, H., Oehme, M., Amado, R., Schneider, H., Graf, U., Velimirov, A., Fließbach, A. \& Niggli, U. 2007. Wheat quality in organic and conventional farming: results of a 21 year field experiment. Journal of the Science of Food and Agriculture 87: 1826-1835.

Müller, T., Thorup-Kristensen, K., Magid, J., Jensen, L.S. \& Søren, H. 2006. Catch crops affect nitrogen dynamics in organic systems without livestock husbandry - Simulations with the DAISY model. Ecological Modelling 191: 538-544.

Pandey, R.K., Maranville, J.W. \& Bako Y. 2001. Nitrogen fertilizer response and use efficiency for three cereal crops in Niger. Communications in Soil Science and Plant Analysis 32: 1465-1482.

Pang, X.P. \& Letey, J. 2000. Organic farming: challenge of timing nitrogen availability to crop nitrogen requirements. Soil Science Society of America Journal 64: 247-253.

Pask, A.J.D., Sylvester-Bradley, R., Jamieson, P.D. \& Foulkes, M.J. 2012. Quantiffying how winter wheat crops accumulate and use nitrogen reserves during growth. Field Crop Research 126: 104-118.

Pimental, D., Hepperly, P., Hanson, J., Douds, D. \& Seidel, R. 2005. Environmental, Energetic, and Economic Comparisons of Organic and Conventional Farming Systems. BioScience 55: 573-582.

Rietberg, P., Van der Burgt, G-L., Talgre, L., Eremeev, V., Sans, F.X., Sukkel, W., Grosse, M., Haase, T., Berner, A., Mäder, P., Willekens, K., Van Gils, B., Delanote, L., Beekman, A., Peigne, J., David, C., Koopmans, C. 2014. Improving nitrogen management in reduced tillage systems by use of green manures and appropriate off-farm inputs: results of TILMAN-ORG. In: Rahmann, G. \& Aksoy, U. (eds.). Building Organic Bridges. Proceedings of the 4th ISOFAR Scientific Conference at the Organic World Congress 2014, 13-15 Oct., Istanbul, Turkey (eprint ID 23985). p. 807-810.

Russelle, M., Blanchet, K., Randall, G. \& Everett, L. 2013. Nitrogen Availability from Liquid Swine and Dairy Manure: Results of OnFarm Trials in Minnesota. Regents of the University of Minnesota. http://www.extension.umn.edu/agriculture/nutrient-management/nitrogen/nitrogen-availability-from-liquid-swine-and-dairy-manure/\#fact. Accessed 12 November 2014.

Seufert, V., Ramankutty, N. \& Foley, J.A. 2012. Comparing the yields of organic and conventional agriculture. Nature 485: 229-232.

Soil Survey Laboratory Staff 1996. Soil Survey Laboratory Methods Manual. Soil Survey Investigations Report No. 42. Version 3.0. The Principal aims of organic agriculture. National Soil Survey Center, Lincoln, Nevada, USA. http://www.ykta.com/index1028. htm. Accessed 15 May 2014

Statistika 2014. Crops cultivated area in Estonia. http://www.stat.ee/34222. Accessed 18 November 2014. 
Tein, B., Kauer, K., Eremeev, V., Luik, A., Selge, A. \& Loit, E. 2014. Farming systems affect potato (Solanum tuberosum L.) tuber and soil quality. Field Crops Research 156: 1-11.

Tsahkna, A. \& Tähtjärv, T. 2008. The new potato variety 'Reet'. Latvian Journal of Agronomy 11: 59-164.

Van Reeuwijk, L.P. (ed). 1995. Procedures for soil analysis. Fifth ed. ISRIC Technical Paper 9. Vageningen, The Netherlands. $112 \mathrm{p}$. Vettik, R. \& Tamm, K. 2013. Relationships between monetary value and dry matter content of manure. Agronomy 2013: 220-225. (in Estonian).

White, E.M. \& Wilson, F.E.A. 2006. Responses of grain yield, biomass and harvest index and their rates of genetic progress to nitrogen availability in ten winter wheat varieties. Irish Journal of Agricultural and Food Research 45: 85-101. 